УДК 159.922

DOI https://doi.org/10.32838/2709-3093/2020.4/33

\title{
Колінець Г.Г.
}

Приватна установа «Вищий навчальний заклад

«Міжнародний гуманітарно-педагогічний інститут «Бейт-Хана»

\section{ПСИХОЛОГО-ПЕДАГОГІЧНІ ОСОБЛИВОСТІ КЕРІВНИЦТВА НАВЧАЛЬНО-ДОСЛІДНИЦЬКОЮ ДІЯЛЬНІСТЮ УЧНІВ}

\begin{abstract}
У статті розглянуто проблему керівництва дослідницькою діяльністю школярів щуодо формування в них високого рівня самоорганізачії та саморегулящії психічної діяльності, розвитку досліднищьких здібностей загалом і мисленнєвих зокрема. Вказано на ї̈ актуальність. Оскільки сучасна освіта знаходиться у процесі реформування, дослідження науковиів спрямовано на пошуки нових шляхів ї̈ удосконалення, розробку нестандартних форм, методів та засобів навчання учнів.

Доведено, що використання можливостей математики як науки і навчального предмета вписується в сучасні зміни реформування освіти. Засвоєння методології наукового пошуку $\epsilon$ однією з основних гуманітарних складових загального математичної освіти. Воно здійснюється у прочесі творчої, досліднищької діяльності, основним змістом якої є розв 'язання навчально-дослідницьких математичних задач і аналіз отриманих результатів.

Проаналізовано основні кониепиї̈ творчої діяльності школярів та специфіки процесу формування дослідницьких здібностей. Результати досліджень зарубіжсни та вітчизняних учених свідчать про важливе значення дослідницьких математичних задач для формування розумової зрілості та розвитку уміння міркувати.

Розкрито теоретичні підходи до поняття навчально-дослідницьких математичних задач та їх характеристик.

Встановлено, що характер спілкування з учителем служить основою психологічної активності школярів, $i$, заодно, основою розумового його розвитку, основою творчого ставлення школяра до самоосвіти. У иьому плані результативність закладається у творчій діяльності самого учителя, оскільки у ній одночасно проектуються як механізм роботи з учнями, так $i$ методи формування елементів дослідниџької діяльності школярів.

3'ясовано психолого-педагогічні умови керівництва навчально-дослідницькою діяльністю школярів, однією з найважливіших серед яких є забезпечення системного підходу, щяо передбачає своєчасне виявлення творчих здібностей учнів, їх інтересу до математичного матеріалу.

Ключові слова: творчість, навчально-дослідницька діяльність, дослідницькі здібності, гнучкість мислення, уміння.
\end{abstract}

Постановка проблеми. Процес формування творчих, дослідницьких здібностей у підростаючого покоління $є$ важливим на даному етапі розвитку суспільства, яке потребує креативних, високоінтелектуальних працівників із гнучким мисленням, здатних вирішувати складні теоретичні та практичні завдання, поставлені життям. Виходячи 3 того, що сучасна освіта знаходиться у процесі реформування, дослідження науковців спрямовано на пошуки нових шляхів іiі удосконалення, розробку нестандартних форм, методів та засобів навчання учнів. Тому проблема керівництва дослідницькою діяльністю школярів щодо формування в них високого рівня самоорганізації та саморегуляції психічної діяльності, розвитку дослідницьких здібностей загалом і мисленнєвих зокрема $є$ актуальною.
Аналіз останніх досліджень і публікацій. Здійснюючи науковий пошук з обраної проблеми, ми враховували результати досліджень зарубіжних та вітчизняних учених. Класичними стали роботи А. Пуанкаре, Д. Пойа, Ж. Адамара, яким притаманні гострота спостережень та глибина осмислених в них феноменів. На вирішення проблеми творчої діяльності школярів та специфіки процесу формування здібностей спрямовано ряд досліджень (А. Пуанкаре, В.А. Роменець, В.О. Моляко [1, с. 41], В.А. Крутецький [2, с. 210], Е.А. Голубєва, О.М. Матюшкін [3, с. 86], Б.М. Теплов, Б.М. Кедров та інші).

Зокрема, А. Пуанкаре вказував, що творчість це не комбінація з уже відомих фактів, а нові практичні значимі ідеї чи продукти. «Творити - це значить вміти розпізнавати, вміти вибирати» $[4$, с. 26]. 
Д. Пойа відзначає важливе значення таких задач для формування розумової зрілості та розвитку уміння міркувати.

У роботах В.І. Андреєва, Л.І. Анциферової та інших розглядались окремі аспекти цієї проблеми, проте вони, загалом, стосувалися виявлення дидактичних умов розвитку і формування когнітивних здібностей дітей.

Потребує досліджень питання щодо встановлення взаємозв'язку між процесом дослідницької діяльності школярів та розвитком особливостей їх творчих здібностей. Залишаються нерозв'язаними питання щодо психолого-педагогічних особливостей керівництва дослідницької діяльністю школярів в умовах навчання.

Постановка завдання. Мета статті - розкрити психолого-педагогічні особливості керівництва дослідницькою діяльністю школярів щодо формування в них високого рівня самоорганізації та саморегуляції психічної діяльності, розвитку дослідницьких здібностей загалом і мисленнєвих зокрема.

Виклад основного матеріалу. Реформування і демократизація школи дали новий імпульс проблемі пошуків шляхів проведення та удосконалення дослідницької діяльності школярів, при цьому вчитель отримав оперативний простір у виборі методів і засобів у залученні учнів до самостійної творчої діяльності під час уроків та у позаурочних заняттях. Один із шляхів вирішення цієї проблеми полягає у створенні умов навчання, умов планомірного проведення умілого керівництва учителями дослідницької роботи учнів у школі.

Усесторонній розвиток школярів - одне з важливих завдань сучасного навчального процесу в школі, причому однією з основних ліній розумового розвитку учнів $\epsilon$ підвищення рівня самоорганізації, саморегуляції психічної діяльності. Ускладнення і розвиток психічної діяльності учнів полягає у виникненні ієрархічних структур дії, які характеризуються складними формами самопідпорядкування основної та допоміжної цілей.

Нами вивчались дослідницька діяльність школярів, розвиток мисленнєвих здібностей у процесі вивчення математики.

Розвиток здібностей учнів значною мірою залежить від широти і глибини взаємостосунків та спілкування школярів 3 учителями. Інакше кажучи, характер спілкування з учителем служить основою психологічної активності школяpiв, i, заодно, основою розумового його розвитку, основою творчого ставлення школяра до самоосвіти, до своїх дій. Завданням учителя є форму- вання в учнів можливості саморозвитку. На жаль, більшість вчителів математики, обмежуючи своє спілкування 3 дітьми в рамками уроку, рамками великого колективу учнів, не спрямовують свої дії таким чином, щоб це дозволило сприяти хоч окремим учням долучитися до саморозвитку, щоб у них виникли можливості та готовність щодо розвитку здатностей трансформувати засвоєні знання для переходу на вищий щабель отримання знань.

Дослідницька діяльність учнів, що передбачає процес отримання суб'єктивно нових знань, може бути здійснена різними шляхами організації навчальної діяльності, пов'язаної з поглибленням знань, отриманих на уроках математики. Використання можливостей математики як науки і як навчального предмета вписується в сучасні зміни реформування освіти. У цьому плані результативність закладається у творчій діяльності самого учителя, оскільки у ній одночасно проектуються як механізм роботи з учнями, так і методи формування елементів дослідницької діяльності школярів.

Засвоєння методології наукового пошуку $є$ однією 3 основних гуманітарних складових частин загального математичної освіти. Воно здійснюється в процесі дослідницької діяльності, основним змістом якої є розв'язання навчальнодослідницьких математичних задач і аналіз отриманих результатів.

У процесі розв'язання навчально-дослідницьких математичних задач відбувається формування готовності учнів до наукової діяльності та усвідомленого вибору професії (переважно у старшокласників) 3 урахуванням потреб суспільства. У них підвищується мотивація потреби досягнень, активізується пізнавальний інтерес, зростають гнучкість математичного мислення, проявляється здатність до логічних міркувань, узагальнення отриманих на уроках знань.

3 метою формування цілісних методологічних знань учень повинен бути включеним в діяльність, подібну науковій, у якій відображаються основні характеристичні особливості наукового математичного процесу: індуктивність математичної творчості; унікальність і сучасність проведених досліджень; інформаційний обмін.

Із цією метою поняття навчально-дослідницьких математичних задач доцільно трактувати відповідно до Д. Пойа [5, с. 351], який виділяє три моменти, які характеризують завдання «науково-дослідного характеру»: «Оскільки ...вибір завдання $\epsilon$, можливо, найважливішим кроком, ... учитель діє так, щоб учні могли взяти участь в постановці завдання ... ». Це - завдання з глибо- 
ким підтекстом, пов'язані з навколишнього нас дійсністю або іншими галузями мислення, вони породжують нові цікаві завдання. У них основну роль відіграють правдоподібні судження (спостереження, припущення, індуктивні умовиводи тощо). Услід за Д. Пойа відзначаємо важливе значення таких задач для розвитку вміння міркувати, формування розумової зрілості. Цей підхід будемо вважати визначенням навчально-дослідницького математичного завдання в широкому сенсі.

Беручи до уваги ці підходи, розглядатимемо навчально-дослідницьке математичне завдання багатокомпонентним завданням із такими характеристиками:

- спільне формулювання навчально-дослідницького завдання (учнями і учителем) на основі опорного завдання з основної навчальної програми;

- варіювання учителем рівня складності, що дозволяє застосовувати такі завдання для забезпечення диференціації та індивідуалізації навчання;

- складання учнями загального плану дослідження обраного об'єкта, що передбачає їх самостійну діяльність із виявлення властивостей i параметрів об'єкта;

- порівняння його властивостей із властивостями аналогічних об'єктів;

- виявлення внутрипредметних і міжпредметних зв'язків;

- спільний пошук раціональної організації обчислень, необхідних для вирішення завдання, в тому числі за допомогою обчислювальної техніки;

- формулювання та аналізування результатів дослідження у процесі переходу від навчальнодослідницького завдання у вузькому сенсі до наукової задачі в широкому сенсі.

Численні спостереження за роботою старшокласників на уроках математики показали, що учні часто здійснюють лише поверховий аналіз умови задачі, а потім шляхом здогадки, використовуючи нерідко метод спроб і помилок, намагаються знайти потрібну відповідь. Уміле та творче керівництво процесом дослідницької діяльності учнів повинно бути спрямованим на вироблення в учнів потреби здійснювати глибокий аналіз умови задачі й досліджувати одержаний результат.

Із метою підвищення зацікавленості учнів на заняттях, на нашу думку, слід використовувати нестандартні математичні задачі, прості, на перший погляд, але які в той же час вимагали б від них певної гнучкості мислення і значної наполегливості. Прикладом таких задач може бути:
Задача № 1. Знайти всі двоцифрові числа, які мають таку властивість: якщо до суми цифр додати квадрат різниці цифр, то буде таке ж число.

Задача № 2. Знайти двоцифрове число, квадрат якого дорівнює кубові суми його цифр.

Простота і зрозумілість умови задач породжують в учнів ілюзію можливості швидкого досягнення успіху, пробуджують інтерес і значну активність. Азарт, породжений уявою про можливість розв'язання задачі шляхом простого підбору чисел, швидко проходить, і в них виникає розуміння необхідності проведення глибокого аналізу умови задачі і встановлення зв'язків між відомими і невідомими величинами. Шляхом бесіди 3 учнями ми виявляли рівень розуміння умови задачі. У випадку виникнення труднощів ставилися запитання, які спрямовували увагу і мислення учнів у певному напрямку. Ці запитання на перших порах були замаскованою підказкою, яка допомагала учням просуватись вперед у розумінні умови чи розв'язанні задачі.

Так, зокрема, приступивши до розв'язання першої задачі, учні зустрілися із труднощами у складанні рівняння, яке б відповідало умові задачі. Одні з них взагалі не змогли скласти відповідне рівняння, а інші склали його невірно, що викликано невмінням записати в узагальненому вигляді двоцифрове число. Поставивши запитання: «Як здійснити позиційний запас двоцифрового числа в розгорнутому вигляді?», фактично даємо підказку учням. Це змушує їх глибше аналізувати кожне слово умови задачі. Позначивши через $x$ число десятків, а через $y$ число одиниць, учні одержують запис двоцифрового числа у вигляді $10 x+y$ і легко складають рівняння $x+y+$ $+(x-y)^{2}=10 x+y$. Шляхом перетворення приводять його до вигляду: $(x-y)^{2}=9 x$. Ми спеціально не зауважуємо, які обмеження треба накласти на числа $x$ та $y$, а учні самостійно до цього ще не додумуються. Вже це свідчить про низький рівень аналітико-синтетичної діяльності школярів і про слабкий розвиток дослідницьких здібностей.

Другий вид труднощів у старшокласників виникає при розв'язуванні складеного рівняння. Сформований стереотип про неможливість розв'язати одне рівняння із двома невідомими практично «паралізує» їх подальшу мисленнєву діяльність.

Стимулюючи до роботи, ми звертаємо увагу школярів (фактично надаючи підказку) на те, що ліва частина рівняння є квадрат якогось числа. Старшокласники зазначають, що й права частина повинна бути квадратом цього числа. Після цього 
один з учнів пропонує знайти це число, добувши квадратний корінь 3 обох частин рівняння. Одержують $|x-y|=3 \sqrt{x}$. Лише тепер, зустрівшись із необхідністю добувати квадратний корінь із числа $\mathrm{x}$, учні приходять до висновку, що треба зразу ж було дослідити, яких значень можуть набувати $x$ та $y$. Виходячи з вигляду рівняння, зазначають, що $x \geq 0$. У цьому проявляється відсутність у школярів навички до дослідницької діяльності. Не враховуючи того факту, що $x$ - це число десятків, вони допускають, що $x$ може дорівнювати і 0 . Запитанням: «А що ми позначили через $x$ ?» - ми виправляємо допущену помилку.

Стереотипні міркування учнів про те, що рівняння можна розв'язати, коли добувається корінь $3 x$, призводить їх до висновку, що $x$ може набувати значень 1, 4, 9, 16 і т.д. Це свідчить знову про слабкий розвиток в учнів дослідницького компоненту. Лише зауваження експериментатора звернути увагу на те, яких значень може набувати $x$ та $y$, призводить до здогадки, що треба було з самого початку встановити їх можливий діапазон: $0<x \leq 9 \mathrm{i}$ $0<y \leq 9$. Після цього, розглянувши випадки $x-y>0$ та $x-y<0$, учні знаходять розв'язок задачі.

Другу задачу старшокласники розв'язали значно швидше. Це пояснюється схожістю між умовами задач, а також усвідомленням необхідності постійно досліджувати дані умови і результати, одержані в процесі розв'язування, що й дозволило учням здійснити перенос засвоєного прийому роботи на розв'язування схожих задач.

Творчість учителя проявляється й у застосуванні диференційованого підходу в процесі вивчення математики, а саме використання диференційованих навчально-дослідницьких завдань із різним ступенем допомоги та різної складності, що успішно сприятиме поступовому переведенню учнів 3 нижчого на вищий рівень навчально-дослідницької роботи - до самостійного іiї проведення.

Пошук шляхів організації структури освітньої системи, які забезпечили б навички самостійного проведення дослідницької діяльності та розвитку розумової активності на основі наявних основних знань і умінь, розуміння пошуку шляхів вдосконалення навчання математики - це завдання не 3 легких. На перший план виступає проблема визначення стратегії і тактики розвитку загальноінтелектуальних здібностей учнів, виявлення школярів, які здатні проявляти і проявляють зацікавленість до пізнання того, що приховано за сторінками шкільного підручника. Важливо викликати в учнів інтерес до здобування нових знань і розвитку пошукової діяльності, спрямованої на пізнання більш глибинних істин, що, вважаємо, може бути здійсненим постановкою посильної задачі перед учнями таким чином, щоб мотиваційна основа давала їм поштовх до саморозвитку. Однією 3 перспективних напрямків вирішення цієї проблеми є актуалізація дослідницьких можливостей математики на сприятливому психофізичному етапі становлення індивіда, розуміючи під цим створення як змістовних, так і організаційних та методичних умов розвитку дослідницьких математичних здібностей учнів.

Процес виконання навчально-дослідницьких завдань сприятиме формуванню в учнів умінь: розвивати спостережливість за математичними об’єктами, мисленнєву операцію порівняння; виконувати аналіз спостережуваних фактів i синтезувати на основі спостережень і аналізу нові умовиводи; проводити математичний експеримент (виконувати обчислення, побудови, вимірювання, моделювати об'єкти); використовувати неповну індукцію і аналогію для висунення гіпотез і перевіряти їх істинність; проводити дедуктивні міркування; узагальнювати отримані факти.

У цьому процесі методологічні знання виступають і як предмет засвоєння, і як основа розвитку дослідницького, творчого мислення.

Висновки. Одними із найважливіших психолого-педагогічних умов керівництва навчальнодослідницькою діяльністю школярів щодо формування в них високого рівня самоорганізації та саморегуляції психічної діяльності, розвитку дослідницьких здібностей загалом і мисленнєвих зокрема $\epsilon$ :

- забезпечення системного підходу, що передбачає своєчасне виявлення творчих здібностей учнів, їхнього інтересу до математичного матеріалу;

- спеціально організоване навчання учнів основам наукових методів дослідження, зокрема формування в школярів знань про суть, логічну послідовність дій та операцій, межі застосування і можливості того чи іншого методу дослідження;

- відбір тематики навчально-дослідницьких завдань, заснований на використанні, в першу чергу, ключових задач основної програми;

- врахування міжпредметного характеру змісту навчально-дослідницьких завдань (математичні задачі з алгебри і геометрії, математики і фізики, математики і інформатики і т.п.);

- використання диференційованих навчальнодослідницьких завдань із різним ступенем допо- 
моги (вчасна і влучна підказка) та різної складності, відповідно до дидактичних принципів переходу від колективної форми діяльності до групової, а від неї - до індивідуальної;

- включення школярів в активну навчальнопізнавальну та дослідницьку діяльність;

- пропонування учням задач для індивідуальної (а частково і для групової) діяльності на вибір із кількох із метою розвитку рівня домагань;

- врахування вікових та індивідуальних особливостей прояву мисленнєвих здібностей;

- розвиток самостійності, оригінальності, гнучкості мислення;
- вдосконалення логічних операцій у процесі розв'язування завдань.

У ході занять 3 учнями учитель виступає як керівник процесу постановки і розв'язання навчально-дослідницьких завдань, який може розпочатись на уроці, а продовжитися в різних формах позаурочної діяльності.

Матеріали нашого дослідження не вичерпують всіх питань, що стосуються вивчення і розкриття психолого-педагогічних особливостей керівництва дослідницькою діяльністю школярів. Подальшу розробку даної проблеми ми вбачаємо у визначенні раціональних шляхів і умов іiі упровадження в позакласній роботі.

\section{Список літератури:}

1. Моляко В.А. Психология решения школьниками творческих задач. Київ : Рад. школа. 1983. 96 с.

2. Крутецкий В.А. Психология математических способностей школьников. Москва : Институт Практической Психологии, 1998. 416 с.

3. Матюшкин А.М., Сиск Д.А. Одаренные и талантливые дети. Bопросы психологии. 1988. № 4. C. 88-97.

4. Колінець Г.Г. Психологічні передумови формування математичних дослідницьких здібностей у старшокласників : дис. канд. психол. наук : 19.00.07 / Інститут психології ім. Г.С. Костюка АПН України. Київ, 1999. $172 \mathrm{c}$.

5. Пойа Д. Математическое открытие: Пер. с англ. Москва : Наука, 1970. 452 с.

\section{Kolinets H.H. PSYCHOLOGICAL AND PEDAGOGICAL FEATURES OF LEADERSHIP OF EDUCATIONAL AND RESEARCH STUDENTS' ACTIVITY}

The article considers the problem of guiding the research activity of students in relation to the formation of a high level of self-organization and self-regulation of mental activity, the development of research abilities in general and mental abilities in particular. Its relevance is indicated. As modern education is in the process of reform, the research of scientists is aimed at finding new ways to improve it, the development of non-standard forms, methods and tools for teaching students.

It is proved that the use of the possibilities of mathematics as a science and a subject fits into the modern changes of education reform. Mastering the methodology of scientific research is one of the main humanitarian components of general mathematical education. It is carried out in the process of creative, research activities, the main content of which is the solution of educational and research mathematical problems and analysis of the results.

The main concepts of creative activity of students and the specifics of the process of formation of research abilities are analyzed. The results of research by foreign and domestic scientists indicate the importance of research mathematical problems for the formation of mental maturity and the development of the ability to think.

Theoretical approaches to the concept of educational and research mathematical problems and their characteristics are revealed.

It is established that the nature of communication with the teacher is the basis of psychological activity of students, and, at the same time, the basis of his mental development, the basis of the creative attitude of students to self-education. In this regard, the effectiveness is embedded in the creative activity of the teacher, because it simultaneously projects both the mechanism of working with students and methods of forming elements of research activities of students.

The psychological and pedagogical conditions of management of educational and research activity of students are found out, one of the most important among them is maintenance of the system approach providing timely revealing of creative abilities of pupils, their interest to a mathematical material.

Key words: creativity, educational and research activity, research abilities, flexibility of thinking, ability. 